DOI: https://doi.org/10.15407/kvt190.04.019

UDC 303.725

K.M. SYNYTSYA, $\mathrm{PhD}$ (Engineering)

Deputy Director for Research

e-mail: ksynytsya@irtc.org.ua

International Research and Training Center for Information Technologies

and Systems of the National Academy of Sciences of Ukraine

and Ministry of Education and Science of Ukraine,

Acad. Glushkova av., 40, Kiev, 03187, Ukraine

\title{
E-LEARNING MODELS ANALYSIS FOR LIFELONG LEARNING
}

Introduction. E-learning models reflect various aspects of ICT application in education but they are not intended for reflecting long periods of time, multiple sources of information and knowledge involved or dynamic control from the learner's side. These and other features are important for lifelong learning modeling aimed at raising the efficiency of learning by the use of individual learner's data.

The purpose of the paper is to review e-learning models that describe frameworks, abstract architectures or reference models for identification of potential prototype for lifelong e-learning model and to outline the requirements to its construction.

Results. The study reveals typical features of the e-learning models grouped according to the level of abstraction and connection to technology and pedagogy. The paper presents an overview of lifelong learning specifics and models that could be considered during the lifelong e-learning modeling. Although none of the discussed models could serve as a unique prototype, some of them could either be integrated in a lifelong e-learning model or guide the modeling. A set of requirements to lifelong e-learning model is suggested.

Conclusion. Lifelong e-learning model should be presented as a set of views that are relevant to actors in e-learning and reflect longevity, multiple sources, context of learning, management and learner's control, collection and sharing the data about learning. The main purpose of it could be in identification of components, tools and processes that should be implemented for intelligent and efficient lifelong learning support

Key words: e-learning, lifelong learning, e-learning framework, reference model, learnercentric model, requirements to e-learning model.

\section{INTRODUCTION}

The most widely known interpretation of the term "e-learning" [1] is related to the use of information and communication technologies (ICT) in learning, education and training thus joining other "electronic" application scopes such as e-health or e-government. The concept evolves in years enlarging the coverage of processes and activities included [2]. Its maturity coincided with a wide spread of the learning management systems (LMS) for distance learning support, therefore, for many users e-learning has been associated with this particular class 
of technologies. Indeed, LMS gradually incorporated functions typical for formal education and became indispensible for educational organizations enabling learning content delivery, assessment, monitoring learning progress, management of groups and reporting results. Although distance learning successfully imitates some types of classroom learning activities (especially lecturing and testing), other types of e-learning, such as simulations and serious games, various learning environments and learning communities, cannot be easily incorporated within one platform but may be instrumental and effective to support professional training, teach certain types of behavior, enable particular learning activities, or answer learning demands.

Although traditional education remains a cornerstone for professional career, other forms of learning and training become important for on-the-job training and professional development, and their share is growing. To emphasize the variety of cognitive activities related to the acquisition of personal, social and professional knowledge, skills and attitudes by an individual through the life a concept of lifelong learning has been introduced [3]. Within lifelong learning, informal and non-formal learning through professional communities, workshops and online sources is a significant part of all learning activities. Therefore, to adequately reflect lifelong learning features, the learning models focused on traditional education have to be extended to embrace other types of learning activities and forms of learning.

\section{PROBLEM STATEMENT}

Lifelong learning offers not only quantitative change in variety of technologies and pedagogical approaches but a change of paradigm. E-learning as an integral part of the daily activities needs to be considered in a context which determines learning objectives and conditions of learning. Thus its efficiency primarily depends not on the technologies or learning strategies applied but on its relevancy to the individual. A model for lifelong e-learning is needed which would reflect its specific features, such as:

- longevity of the learning process, i.e. possibility of taking into account the results of previous learning and experience;

- incorporation of adult learning principles to enable self-regulation and management of individual learning;

- multiple sources of e-learning services and unlimited pool of e-learning resources;

- learning in context, i.e. taking into account parallel activities and environment in which e-learning is taking place.

The purpose of this study is to outline the requirements to the lifelong e-learning model and identify potential prototypes among available models of e-learning. The paper presents a critical review of the models and analysis of their capabilities to reflect certain features of lifelong e-learning. Due to significant number of models related to e-learning, the decision was made to build literature research using not only individual papers but also structured overviews of the research publications. The focus was on conceptual models, frameworks and abstract architectures as candidates for life-long e-learning modeling, the most promising models of each group are shortly outlined. 


\section{LIFELONG LEARNING FEATURES}

Lifelong learning extends the learning timeframe beyond the dedicated period of formal learning and expands the forms of learning experience. It changes the scope of the learning modeling, as well as the level of consideration. Let's outline the main features of the lifelong learning [4].

E-learning for particular category of users (schoolchildren, students, employees) is well researched. Lifelong learning emphasizes on an individual rather than on a particular situation or objective of learning, therefore, one can suppose that observing his or hers behavior over instructional sessions and individual learning experiences, further learning process could be enhanced by filtering and targeting of the learning content. So far provision for individual needs, learning preferences and knowledge level has been done within organization-centric paradigm through adaptation, individualization or personalization models. These studies are focused on a closed learning cycle, well-defined environment or are linked to a particular delivery technology and thus are not applicable to open environments with changing technologies.

Learner-centric view on the learning means that the learner is considered as the only and primary customer, all processes are designed based on his/her requirements and thus the learning content must be collected, tailored and sequenced in a way to meet his/her individual learning objectives taking into account when and how the learning will take place. This situation differs from a system view on learning when the learner has to pass an entrance test to be evaluated and accepted for a particular course. In other words, "course-based" e-learning model designed according to its face-to-face pattern needs to be reconsidered for the purpose of post-graduate and individual adult learning, as it is aimed at construction of the knowledge or building skills from scratch whereas in many cases individual renovation or reconstruction is needed. Although intelligent tutoring systems are able to provide individually-oriented coaching and learning support within a well-defined domain, a generic solution does not exist and thus finding relevant learning content remains an issue.

Essential difference between classical learning and lifelong learning is in the context within which the learning is taking place. Usually learning is considered as a dedicated activity in an isolated environment, i.e. a learner is focused on the learning process during the session time, is able to interact with the learning content as it was envisaged, and does not need interaction with other applications. For lifelong learning it is not the case, as sessions may be interrupted, gaps between the sessions may be substantial so access to previous information or summary needed to proceed, and environment may be noisy or limit some information channels. Besides the real world environment, context is considered as a situation that caused the need for learning. It is usually not stated in the learning objective but is important for efficient on-the-job training.

A concept of lifelong learning allows for consideration of all learningrelated processes as a whole, thus suggesting that all data related to the learning which is relevant for analysis and modeling should be collected in a unified way. This collection may be used as an input for learner modeling in a traditional sense, i.e. to represent a status of his/her knowledge and skills, but also to identify efficient learning strategies and learning style, to determine parameters of 
forgetting and reminding etc. Besides processes directly related to information, knowledge and skills acquisition, lifelong learning embraces related processes of planning, determining the goal of learning, evaluation of results. With rapidly changing user needs and learning technologies, extended learning programs that are planned in advance become obsolete before their completion so dynamic planning is necessary.

Taking into account specific features of the lifelong learning, there is a need for a new e-learning model tolerant to ongoing technology updates, which would support an individual in his/her e-learning through formal education, professional training, as well as various types of individual learning and informal learning activities [5].

\section{GROUPING THE E-LEARNING MODELS}

Along with enhancement of the e-learning technologies and extension of their application in various learning, education and training situations, a wide variety of e-learning models have been introduced. These models reflect some abstract view on organization of learning in technology augmented world, the change of participants' roles and learning environments, but also present some features, functions and components of e-learning implementations. Many attempts have been made to offer some general classification [6-8], however, a comprehensive taxonomy has not been produced yet which may be attributed to the lack of common parameters for the models.

By the time "e-learning" term was coined, computer-based learning and some models of human-computer interaction were already in place although limited to a 1:1 interaction of a learner to a teacher represented by some computer-based course. Gradually, e-learning demonstrated capability to deal with multiple learners and learning resources, facilitate group activities, collaborative work, and peer-to-peer learning. In individual e-learning modeling, the model usually presents knowledge or skills acquisition process, dealing with portions of information for remediation and explanation, selection of tasks and correction of mistakes. Further on, other objects and processes were included into consideration, such as learning resources, their creation, description and management, administrative processes typical for learning organizations, data collection, assessment and evaluation. On the one hand, e-learning has been recognized as a type of learning appropriate for traditional educational body, on the other, learning technologies provided various formats of e-learning: just-in-time, just-for-me, on demand - that are not directly related to any specific organizational structure.

Significant share of the e-learning models are in fact focused on specific issues, such as support of human-computer and human-human communication, use of multimedia, or learner modeling [9]. Despite their narrow focus, some of them may be reconsidered for incorporation within future e-learning frameworks at some level of details, as big data and learning analytics are able to provide sufficient justification for their validity.

The description of the e-learning models that follows will be arranged around models presenting high level of abstraction and intended for soliciting some useful features, identifying effective modeling approach or methodology, determining common conceptual background, as well as a potential for their extension and integration aimed at supporting lifelong e-learning modeling. 
Considering earlier attempts to identify some groups of the models [10], we further focus on:

1) e-learning model as a description of learning/instruction process, focusing on the ability to support particular pedagogical models and learning strategies;

2) e-learning model as an abstract framework, a conceptual model that describes this phenomenon;

3) e-learning model as a reference architecture referring to some commonly known components to outline the structure and functionality;

4) e-learning model as a representation of learner-centric environment.

\section{PEDAGOGICALLY-ORIENTED MODELS}

E-learning models that explicitly state underpinning instructional theory or pedagogical approach belong to the group of models intended for those seeking a theoretical soundness of learning technology use.

Most of the models fit into one of the main approaches featuring the way of learning.

1. An instructional approach that covers strategies intended to teach a learner through a planned sequence of instructional units. They provide variations of a learning cycle including presentation of the content, testing of learner's understanding, feedback on the results and progress to the next unit when results are satisfactory. Variations of this approach are implemented in many e-learning samples, such as distance courses.

2. A constructive approach that emphasizes on explorative or discovery learning. Typically it is related to performing tasks in a learning environment that facilitates learning by feedback, hints, reference material and summarizing. This group is represented by educational games, simulations, micro-worlds.

3. A communicative approach which is based on social learning theories and is transformed into networked learning or communities of practice. Technology role is ranged from the transfer channel to an information source or a virtual partner.

Detailed description of the sample models from each group could be found in [11-13], however, as many other specific models, they do not offer a way to integrate them into a large-scale picture with other resources, approaches and technologies.

A general view on the role of pedagogy in e-learning is presented in the triadic theoretical framework [14], which identifies certain assumptions about learning leading to recent pedagogical models (open and distributed learning, learning within communities), which, in turn, determine a spectrum of instructional strategies to be implemented by the learning technologies. It is implied that emerging technologies being able to support unpredicted forms of learning activities cause extension of pedagogical models. This theory-based design framework for e-learning offers a simple cycle of building learning strategies based on pedagogical models and further implementing them in technologies, which inspire transformations in models by suggesting support for new learning activities. Unlike pedagogically specific models, the framework does not explain precise mapping between the learning strategies and technologies, but it is unique in providing an opportunity for incorporating changes in time. 


\section{CONCEPTUAL FRAMEWORKS}

This group of models contains descriptive models identifying some "dimensions" or "areas of interest" that could be further elaborated and introducing some concepts that still require a detailed description. These models are not related to a particular technology paradigm and are not aimed at providing sufficient information for creation of an abstract architecture of e-learning system. However, the models from this group focus on principles and concepts important to understand the desirable behavior and functions of e-learning systems.

Khan's e-learning framework is a high-level information model inspired by the success of e-learning programs. Eight dimensions are identified as the model components within which tasks and activities for e-learning support may be determined according to the organization's needs. The dimensions include (adapted from [15]): institutional, management, technological, pedagogical, ethical, interface, resources and evaluation. Although these dimensions are not independent, they are useful for outlining groups of closely related tasks and identifying effects of changes such as change of e-learning platform, start of a new learning program or introduction of mobile delivery [16].

Khan's model depicts the dimensions as equal parts of an octagon which is not helpful for determining the priorities of the tasks, relations and potential information flow. For the purpose of our study we suggest extending and adapting the interpretation of the dimensions. Conceptual e-learning framework based on Khan's model providing a "system" view on e-learning organization is shown on Figure. Main components are related to technologies (T), pedagogy (P), resources (R) and interaction (I), ordered in a way to stress the distance of the views and needs of contacts. Interaction (former interface) covers all issues related to communication between the learners, with the teacher or with the learning content. The central part is hold by management $(\mathrm{M})$ as a driving mechanism that is informed by evaluation (E) taking part within the main components and at the system level. Organization $(\mathrm{O})$ component is situated above to demonstrate the division between strategic tasks and tactical tasks, pertaining to the management, information flow and connection to the outer world. Regulations (L) cover legal issues, ethical norms, technical standards, and rules established within the organization thus establishing the framework of operation.
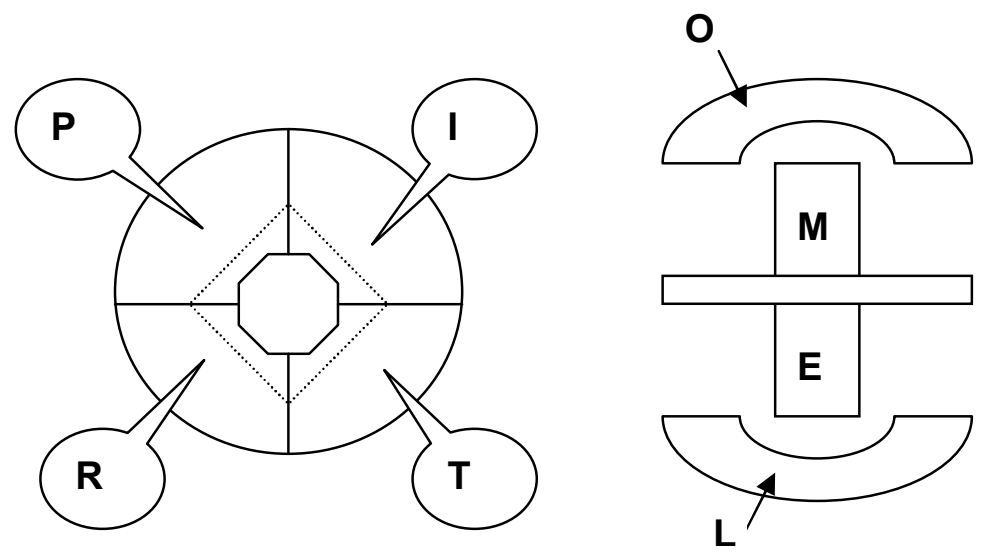

Fig. Adapted Khan's e-learning framework 
Another holistic model [17] considers e-learning as a specific information system and thus e-learning framework is arranged around its core elements - people, technologies and services. People are represented by the stakeholders groups, i.e. those who are involved in e-learning including the developers. Technologies are grouped into those dealing with content, communication and collaboration, and services are represented by e-learning activities implementing pedagogical models and learning strategies. Although based on extensive research of the e-learning implementations, technical standards and conceptual transformations within the field, the framework does not look promising for further refinement.

To summarize, the value of descriptive models is in identification of the purpose and role of e-learning, its relation to traditional learning processes and potential of life-long learning, as well as in depicting conceptual structure for e-learning framework elaboration.

\section{REFERENGE MODELS AND ARCHITECTURES}

This group of models is represented by general outlines of e-learning systems identifying some important components and information flows.

LTSA is a five-layered model detailing the information flow between particular components at each level but it is its third layer that is usually referred to by this acronym. It shows interaction among "processes" and between "processes" and "stores", identifying specific type of communicated information. Both "learner" and "teacher" are included in the model, as well as generalized processes of "delivery" and "assessment". Two "stores" contain learning resources and learner records respectively. This simple model summarizes a common vision of the e-learning systems as a tool for delivery of the learning content and evaluation of the learning results. A nature of its elements, such as metadata for learning resources, multimedia content, interaction context, are further explored and modeled both within and outside of its general framework. Due to its pedagogical and technological neutrality, the LTSA is widely used in various implementations and extensions to reflect adaptability of the learning content, other actors and processes, such as collaboration, content production, and management [18].

In the field of technical standards, the role of a framework is often played by an abstract architecture obtained as a generalization of a particular class of technologies which describes main components, their interconnections, behavior (functions) and other features according to the modeling purpose. An abstract architecture may serve as a reference model for comparison of different systems considered as its technical implementations. It also facilitates integration of different technologies within a system and resolution of compatibility issues based on technical standards which ensure interoperability among particular technologies as implementations of the particular components [19].

Use of standards simplify updates and upgrades of the learning delivery platforms, and extend the choice of learning content provider thus facilitating the growth of distance learning. The core model for distance learning platform is SCORM - a reference model for a particular class of e-learning systems [20]. SCORM describes interaction between a run-time environment which supports e-learning (e.g., LMS) and pre-designed sharable learning content objects combined in a learning resource (e.g., distance course). The model identifies particular processes that perform sequenc- 
ing of the content objects, i.e., selection of the next learning step, based on the learner's output, tracking the learner and processing his/her assessment information, and managing learning content. SCORM model, being a part of a technical standard, is considered to be over-prescriptive by some researchers who pointed out that it is designed having a "system" view in mind.

The growing potential of the internet technologies has changed a focus in e-learning from a system-based to a service-based paradigm which is more appropriate for dynamic nature of e-learning solutions. Service-based organization of e-learning enables smooth and efficient updates of particular functions and incorporation of new features without disruption of existing e-learning [21]. Service-based architecture may be illustrated by three-tier Carnegie Mellon model featuring:

- Infrastructure Tier with internet and service layers, implementing basic infrastructure through common services and protocols,

- Learning Services Tier, comprising basic services related to identification, administration, rights management, common application layer with core learning services typical to the LMS, and tool layer for support of learning content authoring and various learning activities,

- User Agents Tier offering agents for design, management and delivery of e-learning.

Other service-based models follow the same idea of layering the tasks according to their possible relation to other tasks from common to specific. SUN model has a detailed account of functions and their distribution along the layers, IMS model for the enterprises and SIF model put learning services in a context of other business activities and tasks, such as financial, marketing or personnel (human resources) (see https://www.imsglobal.org/specifications.html for referred above and current specifications).

A reference model for online learning communities [22], inspired by a media reference model focused on information transfer and supply-demand business relations, is represented as a set of views that determine organizational, interaction, channel (service) and technological design. The model is created for campus and classroom community of organization, and is arranged around courses rather than particular goals, topics or tasks.

The models of this group are often a generalization of some software systems and therefore are closely related to the implementations in contrast to the descriptive conceptual models. However, reference models are not necessarily linked to particular technologies and provide only core information for further design and development.

\section{LEARNER-CENTRIC MODELS}

This group of models is relatively new and contains those considering a learner as a key actor or customer of the e-learning or relying on a learner-centric paradigm. Therefore, they tend to indentify the value of learning technologies for a particular individual by design or adaptation.

The research [23] is focused on a learner-centered approach and results in a model presented as a set of 14 learner-centered psychological principles describing the groups of cognitive and meta-cognitive, motivational and affective, developmental and societal, as well as individual differences factors important for 
implementation of e-learning effective for each individual. An important role among educational processes belongs to the networking, collaboration and inquiry with the ultimate goal to support learning in context, anytime, anywhere. Learner-centered approach is a core of online andragogical model that describes expected features of e-learning for adult learners [24]. The model changes the role of the educator from the "director of learner" to the knowledgeable supporter, and outlines new tasks which a mature learner can perform, such as mutual planning, goal setting and self-regulation.

Learner-centric models may be intended for adaptation of learning environment to the individual needs but also to describe the learner's vision of the instruments facilitating his/her learning. A concept of personal learning environment [25] reflects the idea of supporting the learner through a collection of tools.

To identify essential functions and components of a personal learning environment (PLE), users' draft models have been collected [26]. Common part of all drafts is a set of tools for accessing information or knowledge sources, for communication collaboration and sharing (publishing) which are either referred to by their function or named by respective technologies. In some drafts content creation tools are also mentioned. One can see that PLE is considered as a support for informal learning and lacks management or monitoring tools as well as data collection for self-regulation.

Most drafts picture a "current situation", i.e. present how existing technologies could be combined to support individual learning right now. They don't take into account longevity factor or set requirements to technologies based on the learner's needs. The tools or functions within the draft are independent and don't exchange information either directly or through the agents, as that was the case at the time of study.

Learner's view on the way information and knowledge may be acquired by e-learning and other ICT is important for understanding lifelong learning requirements and, despite of the above-mentioned limitations, should be incorporated in the lifelong e-learning model.

\section{REQUUIREMENTS TO LIFELONG LEARNING MODELING}

A thorough analysis of e-learning models [13], including traditional instructional models, networked and collaboration learning, dialogue and conversational learning, as well as specific cases for adaptive instruction and learning objects as units of instruction, demonstrated that they cannot be easily integrated into a single framework. The detailed analysis of the most promising models in this paper demonstrated that no single model could be expanded for lifelong e-learning purposes. However, a study of the modeling approaches allows concluding that lifelong e-learning being a complex phenomenon may be adequately presented by a set of models rather than a single one. For this purpose, a set of views could be considered to present conceptual models of all stakeholders (learners, learning organizations, teachers, developers). Learnercentric model (learner's view) is a candidate for primary model which will identify the tasks related to the learning process and types of resources involved. System's view could be a collection of abstract architectures implementing particular tasks. 
A set of views should be able to reflect the following:

- longevity of the modeling, i.e. potential changes in objects, characteristics, parameters that in other cases are considered as static;

- capability to collect data which may be useful to guide e-learning and raise its efficiency;

- maintaining a kind of learner's model or profile representing current state of competencies and capabilities of an individual;

- context of the learning, such as performance support, learning platform or environment;

- management of the e-learning processes and potential use of intelligent agents for various forms of assistance.

\section{CONCLUSION}

E-learning modeling is a valuable mechanism for communicating essential features of the systems and services in learning, education and training. Variety of the models demonstrates the complexity of the task and absence of the unified understanding of the e-learning processes, participants and components.

Lifelong learning extends the scope of subjects, objects, tools and processes that are to be included in the model and raises the level of consideration. On the one hand, it is concerned with meta-tasks, e.g. how different sources of learning experience may be purposefully combined; what effect they have on a resulting learner's competency if not coordinated; what mechanisms could be employed to reflect a learner's knowledge state using learner's data ageing due to natural forgetting and global knowledge space changes caused by science, technology and communication progress; what kind of "push" and "pull" technologies may be valuable for implementation in a personal learning assistant helping to plan and select individual learning experience. On the other, it brings attention to specific learning situations that should be accounted for, such as microlearning or learning by doing, and their potential combination with proven strategies for individual knowledge construction support.

It is expected that lifelong e-learning framework may reflect essential features of the core models through a set of views. However, the main value of the lifelong e-learning model could be not in a combination of the specific models into a common schema but rather in identification of components, tools and processes that should be implemented for intelligent and efficient lifelong learning support. Further research is needed to detail the list of requirements and coordinate it with each particular model presenting a view. It is important to study potential mechanism for coordinating views, as the learner's view alone could be considered as a task-based model, as a conceptual framework based on extended Khan's model and as an abstract architecture.

\section{REFERENCES}

1. ISO/IEC 2382-36. Information technology. Vocabulary. Information technology for learning, education and training.

2. Manako A.F., Sinitsa E.M. (2014) Innovative electronic research and education spaces: a view through the prism of transformations. Educational Technology \& Society. 17 (1), 546-577 (in Russian).

3. Odabasi, F., Kuzu, A. \& Gunuc, S. Characteristics of lifelong learner. In P. Resta (Ed.), Proceedings of SITE 2012 - Society for Information Technology \& Teacher Education 
International Conference (March 5-9, 2012, Austin, Texas). Austin, Texas, 2012. P. 4037-4039.

4. Lawson M., Askell-Williams H., Murray-Harvey R. "The attributes of the lifelong learner." A report prepared for the Queensland Studies Authority. Flinders Univ. Adelaide (2006). $101 \mathrm{C}$.

5. Sandyga I.V., Manako A.F., Voychenko A.P., Sinitsa E.M. Lifelong learning as a factor of information society development. Proc. $5^{\text {th }}$ International conference Information technologies in education for all (November 23-25, 2010, Kiev). Kiev, 2010. P. 23-25 (in Russian).

6. Vaishali Suryawanshi, Dayanand Suryawanshi, Fundamentals of E-Learning Models: A Review. Innovation in engineering science and technology (December, 2015, Maharashtra). Maharashtra, 2015. IOSR Journal of Computer Engineering (IOSR-JCE) P. 107-120.

7. Wentling T., Waight C., Gallaher J. et. al. e-learning - A Review of Literature. NCSA, Univ.Illinois, 2000, $73 \mathrm{p}$.

8. Leal J.P., \& Queirós R. (2010). E-Learning Frameworks: a survey. Proceedings of International Technology, Education and Development Conference (March 8-10, 2010, Valencia). Valencia, 2010.

9. Sinitsa E.M. (1993) Probabilistic models for learner knowledge testing. Intellectualization of computer-based learning technologies. Academy of sciences of Ukraine. Glushkov Institute for cybernetics, 39-41. (in Russian).

10. Wilson S., Olivier B., Jeyes S., Powell A., \& Franklin T. (2004). A technical framework to support e-learning. JISC.

11. Garrison D.R. (2011). E-learning in the 21st century: A framework for research and practice. Taylor \& Francis. $2^{\text {nd }}$ edition.

12. Glancy F.H., \& Isenberg S.K. A Conceptual ELearning Framework. European, Mediterranean \& Middle Eastern Conference on Information Systems. (May 30-31, 2011, Athens). Athens, 2011. P. 636-650.

13. Mayes T. and de Freitas S. (2004) Review of e-learning theories, frameworks and models. London: Joint Information Systems Committee.

14. Dabbagh N. (2005). Pedagogical models for E-Learning: A theory-based design framework. International Journal of Technology in Teaching and Learning, 1 (1), 25-44.

15. Khan B. H. (2000). A Framework for E-Learning. Distance Education Report, 4(24), 3-8.

16. Synytsya K. Adding mobility to the ADL language course. The International Scientific Conference eLearning and Software for Education (April 25-25, 2013, Bucharest). Bucharest, 2013. Vol 2. P. 147-152.

17. Aparicio M., Bacao F., \& Oliveira T. (2016). An e-Learning Theoretical Framework. Educational Technology \& Society, 19 (1), 292-307.

18. Ismail J. (2001). The design of an e-learning system: Beyond the hype. The Internet and Higher Education, 4(3), 329-336.

19. Synytsya K. (2006). Standards for Learning Technologies: Overview and Directions. Communications of IICM, 8(2), 5-15.

20. Wisher R., Khan B. (2010), Learning on Demand. ADL and the Future of e-Learning.

21. Dagger D., O'Connor A., Lawless S., Walsh E., \& Wade V. P. (2007). Service-oriented e-learning platforms: From monolithic systems to flexible services. Internet Computing, IEEE, 11(3), 28-35.

22. Seufert S., Lechner U., \& Stanoevska K. (2002). A reference model for online learning communities. International journal on E-learning, 1(1), 43-54.

23. McCombs B., \& Vakili D. (2005). A learner-centered framework for e-learning. The Teachers College Record, 107(8), 1582-1600.

24. Livingstone D. W. (2001). Adults' informal learning: Definitions, findings, gaps and future research. WALL Working Paper No.21. $50 \mathrm{p}$.

25. Attwell G. (2007). Personal Learning Environments - the future of eLearning?. Elearning papers, 2(1), 1-8. 
26. Milligan C.D., Beauvoir P. Johnson, M.W. Sharples, P. Wilson S. and Liber O., 2006, Developing a reference model to describe the personal learning environment. EC-TEL. LNCS (1-4 October, 2006, Crete). Crete, 2006. Vol. 4227. P. 506-511).

Received 17.09.2017

\section{ЛИТЕРАТУРА}

1. ISO/IEC 2382-36. Information technology. Vocabulary. Information technology for learning, education and training.

2. Манако А.Ф., Синица Е.М. Инновационные электронные научно-образовательные пространства: взгляд сквозь призму трансформаций // Международный журнал "Образовательные технологии и общество" (Educational Technology \& Society). 2014. - V. 17. - №. 1. - C. 546-577.

3. Odabasi, F., Kuzu, A. \& Gunuc, S. Characteristics of lifelong learner. In P. Resta (Ed.), Proceedings of SITE 2012 - Society for Information Technology \& Teacher Education International Conference (March 5-9, 2012, Austin, Texas). Austin, Texas, 2012. P. 4037-4039.

4. Lawson M., Askell-Williams H., Murray-Harvey R. "The attributes of the lifelong learner." A report prepared for the Queensland Studies Authority. Flinders Univ. Adelaide (2006). $101 \mathrm{C}$.

5. Сандыга И.В., Манако А.Ф., Войченко А.П., Синица Е.М. Непрерывное обучение как фактор развития информационного общества. Материалы 5 Межд.конф. «Информационные технологии в образовании для всех» ITEA-2010. (23-25 ноября, 2010, г. Киев). Киев, 2010. С.23-25.

6. Vaishali Suryawanshi, Dayanand Suryawanshi, Fundamentals of E-Learning Models: A Review. Innovation in engineering science and technology. (December, 2015, Maharashtra). Maharashtra, 2015. IOSR Journal of Computer Engineering (IOSR-JCE) P. 107-120.

7. Wentling T., Waight C., Gallaher J. et. al. e-learning - A Review of Literature. NCSA, Univ.Illinois, 2000, $73 \mathrm{p}$.

8. Leal J.P., \& Queirós R. (2010). eLearning Frameworks: a survey. Proceedings of International Technology, Education and Development Conference. (March 8-10, 2010, Valencia). Valencia, 2010.

9. Синица Е.М. Вероятностные модели тестирования знаний обучаемого / В сб.: Интеллектуализация компьютерных технологий обучения. АН Украины, Ин-т кибернетики им. Глушкова, 39-41, 1993.

10. Wilson S., Olivier B., Jeyes S., Powell A., \& Franklin T. (2004). A technical framework to support e-learning. JISC.

11. Garrison D.R. (2011). E-learning in the 21st century: A framework for research and practice. Taylor \& Francis. $2^{\text {nd }}$ edition.

12. Glancy F.H., \& Isenberg S.K. A Conceptual ELearning Framework. European, Mediterranean \& Middle Eastern Conference on Information Systems. (May 30-31, 2011, Athens). Athens, 2011. P. 636-650.

13. Mayes T. and de Freitas S. (2004) Review of e-learning theories, frameworks and models. London: Joint Information Systems Committee.

14. Dabbagh N. (2005). Pedagogical models for E-Learning: A theory-based design framework. International Journal of Technology in Teaching and Learning, 1 (1), 25-44.

15. Khan B. H. (2000). A Framework for E-Learning. Distance Education Report, 4(24), 3-8.

16. Synytsya K. Adding mobility to the ADL language course. The International Scientific Conference eLearning and Software for Education (EISE). (April 25-25, 2013, Bucharest). Bucharest, 2013. Vol 2. P. 147-152.

17. Aparicio M., Bacao F., \& Oliveira T. (2016). An e-Learning Theoretical Framework. Educational Technology \& Society, 19 (1), 292-307.

18. Ismail J. (2001). The design of an e-learning system: Beyond the hype. The Internet and Higher Education, 4(3), 329-336. 
19. Synytsya K. (2006). Standards for Learning Technologies: Overview and Directions. Communications of IICM, 8(2), 5-15.

20. Wisher R., Khan B. (2010), Learning on Demand. ADL and the Future of e-Learning.

21. Dagger D., O'Connor A., Lawless S., Walsh E., \& Wade V. P. (2007). Service-oriented e-learning platforms: From monolithic systems to flexible services. Internet Computing, IEEE, 11(3), 28-35.

22. Seufert S., Lechner U., \& Stanoevska K. (2002). A reference model for online learning communities. International journal on E-learning, 1(1), 43-54.

23. McCombs B., \& Vakili D. (2005). A learner-centered framework for e-learning. The Teachers College Record, 107(8), 1582-1600.

24. Livingstone D. W. (2001). Adults' informal learning: Definitions, findings, gaps and future research. WALL Working Paper No.21. $50 \mathrm{p}$.

25. Attwell G. (2007). Personal Learning Environments-the future of eLearning?. Elearning papers, 2(1), 1-8.

26. Milligan C.D., Beauvoir P. Johnson, M.W. Sharples, P. Wilson S. and Liber O., 2006, October. Developing a reference model to describe the personal learning environment. In EC-TEL. LNCS (1-4 October, 2006, Crete). Crete, 2006. Vol. 4227. P. 506-511.

Получено 17.09.2017

К.M. Синиця, канд. техн. наук, старш. наук. співроб., заступник директора з наукової роботи

e-mail: ksynytsya@irtc.org.ua

Міжнародний науково-навчальний центр інформаційних технологій та систем НАН України і МОН України, пр. Акад. Глушкова, 40, м. Київ, 03187, Україна

\section{АНАЛІЗ МОДЕЛЕЙ ЕЛЕКТРОННОГО НАВЧАННЯ ДЛЯ НЕПЕРЕРВНОГО НАВЧАННЯ}

Наведено коротку характеристику моделей електронного навчання та визначено основні групи, на базі яких $є$ можливим створення моделі неперервного електронного навчання. Розглянуто специфічні характеристики неперервного навчання, які визначають вимоги до такої моделі. Показано, що така модель має містити кілька проекцій, які відображають точку зору учня, розробника, постачальника навчальних послуг, системи освіти в цілому, бути технологічно і педагогічно нейтральною та враховувати проблеми керування, пов'язані зі змінами умов та мети навчання.

Запропоновано розвиток моделі Хана для відображення процесу неперервного навчання, що полягає у розширенні та адаптуванні інтерпретації компонентів цієї моделі за рахунок визначення їх призначення в умовах особистісно-орієнтованого моделювання, а також формування структури їх взаємодії. Зазначено, що головна мета моделі неперервного навчання в електронній освіті полягатиме не тільки у поєднанні часткових моделей в загальній схемі, а і в ідентифікації компонентів, інструментів і процесів, які слід запровадити для інтелектуальної та ефективної підтримки навчання протягом усього життя.

Ключові слова: електронне навчання, неперервне навчання, структурна модель е-навчання, еталонна модель, вимоги до моделі е-навчання. 
E.M.Синица, канд. техн. наук, старш. науч. сотр. заместитель директора по научной работе e-mail: ksynytsya@irtc.org.ua

Международный научно-учебный центр информационных технологий и систем НАН Украины и МОН Украины, пр. Акад. Глушкова, 40, г. Киев, 03187, Украина

\section{АНАЛИЗ МОДЕЛЕЙ ЭЛЕКТРОННОГО ОБУЧЕНИЯ ДЛЯ НЕПРЕРЫВНОГО ОБУЧЕНИЯ}

Дана краткая характеристика моделей электронного обучения и выделены основные группы, на базе которых может быть создана модель электронного обучения на протяжении жизни. Рассмотрены специфические черты непрерывного обучения, определяющие требования к такой модели. Показано, что такая модель должна содержать несколько проекций, отображающих видение обучаемого, разработчика, поставщика учебных услуг, системы образования в целом, быть технологически и педагогически нейтральной и учитывать задачи управления, связанные с изменением условий и целей обучения.

Предложена модификация модели Хана для отображения процесса непрерывного обучения, которая заключатся в расширении и адаптации интерпретации компонентов этой модели за счет определения их предназначения при индивидуальноориентированном моделировании и формировании структуры их взаимодействия. Отмечено, что основная цель модели непрерывного обучения в электронном образовании заключается не только в интеграции частичных моделей в общей схеме, а и в идентификации компонентов, инструментов и процессов, необходимых для реализации интеллектуальной и эффективной подержки обучения на протяжении всей жизни.

Ключевые слова: электронное обучение, непрерывное обучение, структурная модель е-обучения, эталонная модель, требования к модели е-обучения. 